\title{
The DBR Methodology for the Study of Context in Learning
}

\author{
Jacqueline Bourdeau \\ jacqueline.bourdeau@licef .ca \\ TELUQ, Montreal, Quebec, Canada
}

\begin{abstract}
In the Design-Based Research (DBR) methodology, the process is as important as the product, and each iteration is considered a sub-result leading to the next one. This methodology is being used in the TEEC project, to both study and elaborate solutions for Learning in Context. This paper describes the origins of the project, as well as the steps taken to conduct it, with a perspective for future work. The DBR methodology is presented as applied in the TEEC project $($ TEEC $=$ Technologies Educatives et Enseignement en Contexte).
\end{abstract}

Keywords: Design-Based Research, DBR, Methodology, Modelling, Context, Learning, Intelligent Tutoring Systems

\section{Introduction}

This paper addresses methodological issues in the study of context in learning, involving the design and development of innovative solutions to foster awareness regarding the context in both humans and machines. To start with, the DBR methodology is presented and we explain the reasons for which it has been preferred to others for sustaining a project focussing on context in learning. Second, the project under the acronym TEEC (Technologies Educatives et Enseignement en Contexte, in English Educational technologies and teaching in context) is described, from its inception to the hypotheses and objectives that were set. Following this, we introduce the main elements composing the solution to be designed, developed and tested: the instructional design, the ideas of the context calculator (MazCalc) and of the Context-Aware Intelligent Tutoring System (CAITS), the iterations to test each element of the solution, as well as data collection and trace analysis. As a synthesis of the methodological approach, an overview of the DBR iterations throughout the TEEC project is provided, illustrating the process of making ideas and tools evolve towards a robust solution. Finally, the current status of the project and future work as planned are described.

\section{$2 \quad$ What is Design-Based Research?}

The Design-Based Research methodology (thereafter called DBR) has its roots in the pioneering work by Brown [1], under the name of Design experiments, in an effort to reduce the gap between lab research and in situ research, and to allow a process 
by which both theory and practice can evolve together, based on a design process. It relies upon a cybernetic principle where the result of each loop changes the behaviour of a system. DBR then evolved into a full methodology which was claimed by the DBR Research Collective and published in the Educational Researcher Journal [2] sustained by an article in the Journal of the Learning Sciences [3], another one by Wang \& Hannafin entitled Design-based research and technology-enhanced learning environments [4], another one by Herrington et al. [5], and the book chapter by Reimann [6]. It has been applied in numerous pedagogical innovations $[7,8,9,10,11,12]$. DBR can be characterized as a microsystemic methodology, based on system science principles, mainly the feedback loops mechanisms, or iterations, and the goal of comprising the complexity of an authentic situation to study it. In contrast to experimental research, it does not aim to isolate nor control. Unlike participatory design, it promotes the development of theoretical knowledge simultaneously to the design of artefacts.

To our knowledge, DBR has not been applied to study the design of collaborative learning, nor the design of context-aware learning environments.

\section{The Inception of the TEEC Project}

The TEEC project was born in 2012, and is grounded in previous work both at CRREF (Université des Antilles, French West Indies) on context in learning and at LICEF (TÉLUQ, Canada) on Instructional Design and Intelligent Tutoring Systems. We worked on why and how to reconcile the intellectual traditions of french didactics with instructional design and intelligent tutoring systems.

The first starting point was that science learning tends to happen out of context, or even out of scope that context could be inherent to science learning. The second one was that context modelling was also absent in ITS research, which has sofar mainly concentrated on modelling the domain, the learner and the tutoring [13,14].

We considered several options to take context into account, among them ignoring context, putting it aside, or putting it on center stage. We then elaborated the hypothesis that learning would be most productive if we can stimulate what we call context effects in a learning scenario. To do so, we need to have: a generic learning scenario capable of producing context effects, a model of context that would allow us to calculate and predict the potential of two contexts to produce the context effect, and several experimentations to test and verify this hypothesis. We called our model the CLASH model, since it aims at fostering learning through a clash between contrasting contexts (similar to the Aha! Effect), as a manifestation of a cognitive clash, leading to a conceptual change in learners [15].

We also soon realized that in order to have a scientific tool to help our design and our predictions, it would be necessary to build a context calculator (later called MazCalc), that would contain the contextual parameters, compute the predicted context effect, and guide the design of the learning scenarios. Finally, we envisioned an intelligent tutoring system that would be context-aware and therefore adaptive and reactive to contextual elements in the learning process, relying on the context analysis 
performed by the MazCalc software. This system would also contain authoring rules and allow an instructional designer to adapt, improve and edit productive learning scenarios.

The hypotheses that we formulated are the following:

1) An instructional scenario, designed as to produce a clash between two contrasted contexts, for students working collaboratively on similar topics and shared tasks, that can foster learning while distinguishing basic notions from context-dependent elements, and stimulate the awareness of the gap between their observations and their mental models, which leads to a conceptual change.

2) Context modelling allows to instantiate and calculate the gaps between contexts using parameters

3) It is then possible to predict a context effect based on 1) et 2).

The objectives are to:

$\square$ Create and test an instructional model based on the emergence of context effects to foster conceptual change (CLASH)

$\square$ Elaborate a characterization system to predict context effects using indicators for each domain and topic

Design and develop a software tool with a meta-model of context, a simulator, and an editing interface to instantiate parameters and equations specific to a domain and to a topic; test it, document it with user guides and release it as an open resource (MazCalc)

Design learning scenarios and experiments in various domains, topics, and academic levels

$\square$ Design and develop a Context-Aware Intelligent Tutoring System (CAITS), with MazCalc as its core, and authoring and tutoring services.

In order to achieve these objectives and test these hypotheses, while working on many fronts at the same time, we needed a methodology that would: 1) allow us to tackle the design of several components at the same time, 2) be concerned both with theory and practice, 3) account for the complexity of the learning situation, 4) respect the authenticity of the learning tasks, 4) allow us to produce results repeatedly along the development of the project, 5) allow us to test not only the hypotheses but also the components.

The DBR methodology proved to be the best candidate for our project, despite the fact that it had not been applied yet to the study of context in learning, nor to telecollaborative learning, nor to the design of a context-aware learning environment. We are fully aware of the challenge related to this innovation, and we expect to live up to this challenge during the project.

To achieve our objectives, we also needed to design several components: an instructional scenario to set the structure of learning activities with their constraints while leaving room for emergent events; a software tool to calculate the contrast between two contexts, to predict the productivity of the scenario, and eventually to modify it; a smart learning environment aware not only of the context itself, but of the context as integrated with the domain and the learner models. 
The following three sections introduce the components involved: 1) the instructional design process and its product, the learning scenario; 2) the MazCalc software and the learning environment, 3) the first three design experiments. The last two sections highlight the data collection and trace analysis processes, and the future work as planned for the next three years.

\section{The Instructional Design for the CLASH Model}

Instructional design is a methodology for designing instruction that pertains to the domain of Educational Technology, and proposes to apply engineering techniques to design instruction [16]. Fundamentally, the design process is composed of: analysis, design, development, implementation, and evaluation. The main instrument is called the learning scenario, which is defined as a structured set of components that specifies objectives, actors, activities, resources, tools, time and space, and which can be applied at different scales (course level, module level). Every specification is justified by its relevance to the objectives, and by the coherence with other elements.

We found out that instructional design would be a cornerstone to designing learning scenarios leading to the awareness of context and of its role in science learning. This is why we envisioned building a generic learning scenario that would allow us to produce and test the eventual context effect, draw conclusions, and improve our model. The scenario is oriented to reach a goal and to meet objectives, which can be either measured or observed. The inspiration for our generic scenario was the Jigsaw scenario [17], known for producing learning though collaboration, and which we adapted to our view. The main idea is to have two teams of learners, in contrasted contexts, working on the same scientific object or phenomenon, performing similar tasks, collecting observation data, exchanging on this object, and discovering the role of context in this learning.

The challenges offered by the TEEC project in terms of instructional design are manifold: negotiation about topics and activities among teachers and (eventually) learners, mechanisms for collaboration, tools for communication and sharing, and for data collection, etc. The main constraints and expectations are listed in Table 1.

Collaborative learning supported by technology (or Computer-Supported Collaborative Learning, CSCL) has been an object of study for more than 10 years ${ }^{1}$. Instructional scenarios or scripts are considered a basic tool for orchestrating and studying CSCL. Fostering discussion among learners experiencing differentiated contexts, cultures or beliefs has been successfully tested in CSCL [18], either inspired by a jigsaw type of scenario [17], or by exploiting international socio-cultural and economical differences [18].

1 The International Journal of Computer-Supported Collaborative Learning (ijCSCL) was founded in 2006 by the International Society of the Learning Sciences (ISLS). See http://ijcscl.org/ 


\begin{tabular}{|c|c|}
\hline $\begin{array}{l}\text { Constraint 1: } \\
\text { Hypotheses }\end{array}$ & $\begin{array}{l}\text { 1) An instructional scenario, designed for allowing a conceptual } \\
\text { change through a clash between two contrasted contexts among learners } \\
\text { collaborating on shared topics will foster the learning of the role of con- } \\
\text { text in the domain studied } 2 \text { ) modelling the context makes it possible to } \\
\text { calculate parameters of the context as well as the gap between two con- } \\
\text { texts, 3) It is possible to predict a context effet based on 1) and 2). }\end{array}$ \\
\hline $\begin{array}{l}\text { Constraint 2: } \\
\text { CLASH Model: }\end{array}$ & $\begin{array}{l}\text { Experience a context effect allows learners to differentiate the role of } \\
\text { context in a domain, and to differentiate what is common to all from } \\
\text { what is context-dependent }\end{array}$ \\
\hline $\begin{array}{l}\text { Constraint 3: } \\
\text { Collaborative learning } \\
\text { scenario }\end{array}$ & $\begin{array}{l}\text { A structured set of learning activities with its calendar; specification } \\
\text { of actors, activities, resources, time/space; } 2 \text { groups (15-30 participants), } \\
\text { 3-6 topics, 3-6 teams per group; pedagogical resources, investigation or } \\
\text { inquiry tools; communication and sharing virtual environment }\end{array}$ \\
\hline $\begin{array}{l}\text { Constraint 4: } \\
\text { MAZCALC software }\end{array}$ & $\begin{array}{l}\text { Context calculator, a software tool to enter topics, parameters and } \\
\text { their values (quantitative or qualitative) and compute the gap between } \\
\text { two contexts, both for predicting and verifying the productivity of a } \\
\text { specific scenario }\end{array}$ \\
\hline $\begin{array}{l}\text { Constraint 5: } \\
\text { Trace analysis }\end{array}$ & $\begin{array}{l}\text { Analysis of the data collected to inform the study of context in learn- } \\
\text { ing; analysis of interactions (among learners, with the learning environ- } \\
\text { ment) and of emotions, for detecting and studying the manifestations of } \\
\text { context effects }\end{array}$ \\
\hline Expectations & $\begin{array}{l}\text { Produce results for the testing and the improvement of each compo- } \\
\text { nent: hypotheses; CLASH model; instructional scenario; MAZCALC } \\
\text { software; trace analysis, according the DBR methodology for a series of } \\
\text { feedback loops. Inform the overall design and the organisation of the } \\
\text { design experiments. }\end{array}$ \\
\hline
\end{tabular}

Table 1. Constraints and expectations for a TEEC learning scenario

Our approach resonates with Gropper's five recommendations [16] for instructional design research: 1) Reserve the word 'theory' for testable and verified propositions; 2) Translate propositions stated in rationales for a favoured model into testable form; 3) Do the research needed to verify the propositions so translated; 4) Structure or restructure a model based on results from multiple such tests; 5) Evaluate the model as a whole, for reliability and validity of implementation.

\section{Imagining the MazCalc Software and the ITS Architecture}

In order to test our hypotheses, we imagined a situation where we would be able to calculate and predict the productivity of a scenario where two teams of learners would work on the same scientific topic, become aware of the differences due to context, exchange about it, and distinguish what is common and what is contextdependent. For this purpose, we conceived a context calculator, called MazCalc, 
which is a software tool to calculate the contrast between two contexts, to predict the productivity of the scenario, and eventually to modify it for improving the probability of success, that is to obtain accurate learning in and among learners. Starting with the identification of parameters belonging to the domain studied and the topics selected, it is then possible to assign values to these parameters, related to the expected context model. Specific properties related to each parameter provide the rules that can then be applied for the gap calculation. The history as well as the perspectives on the MazCalc are reported by Anjou et al. [17] in this volume.

In our vision, MazCalc would be at the core and would serve the purpose of a Culturally-Aware Intelligent Tutoring System (CAITS). In the tradition of ITS research, the basic architecture is composed of 4 modules: the domain, the learner and the tutoring models, plus the user interface $[13,14]$. To our knowledge, there has been no attempt to design an ITS that would contain some modelling of the context and would be capable of changing its behaviour based on its knowledge of context. In order to serve our goals, a conceptual architecture was designed, and the first steps taken towards a meta-model of context for the calculator [20,21].

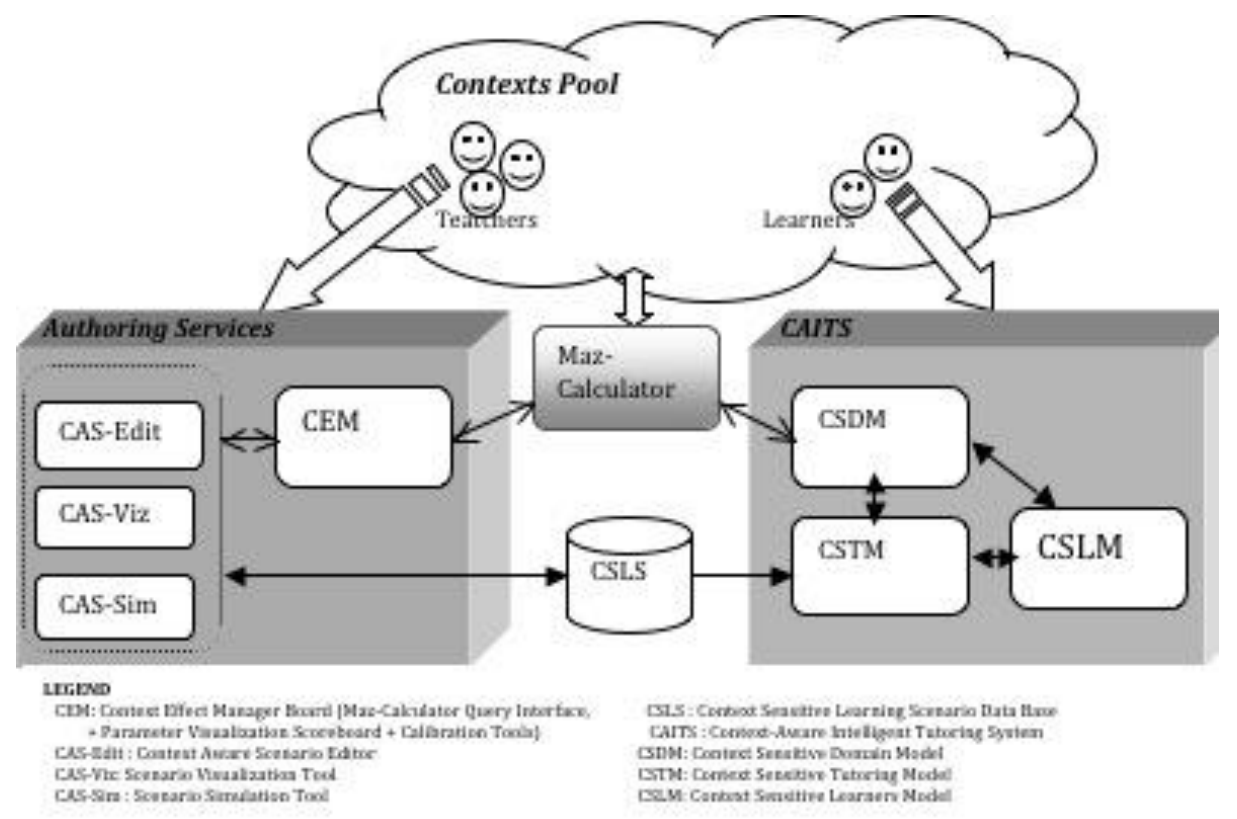

Fig. 1. The CAITS Conceptual Architecture

Having stated the hypotheses, drawn a model, drafted the tools, and adopted a methodology, we started organizing and preparing the first in situ experiments. 


\section{Three Design Experiments}

\subsection{The First Experiment in Biology: Gounouj}

The first experiment was in Biology in 2013 and was called Gounouj, because it focussed on the frog (gounouj being the term for frog in guadelupean creole), and how it differs between a tropical country (as in Guadelupe) and a nordic one (as in Quebec), although belonging to the same species. We designed the scenario so as the two teams would be focussing on the same object, but would become aware of the context dependencies by making observations and collecting data in their close environment. The frog was chosen for its contrasting potential, since Guadeloupe has the smallest frog, and Quebec the largest one in North America. The six topics for both teams were: calls, nutrition, morphology and taxonomy, sustainable development and relationships with humans, and development. As a first stage of technological integration, the instructional scenario has been implemented in a Learning Management System (LMS, Moodle), in order to interconnect the activities with the sources needed, and to facilitate the recording and the tracing of the data (Fig.2). The initial scenario can be modified along the experiment to make room for emergent activities or requests from learners.

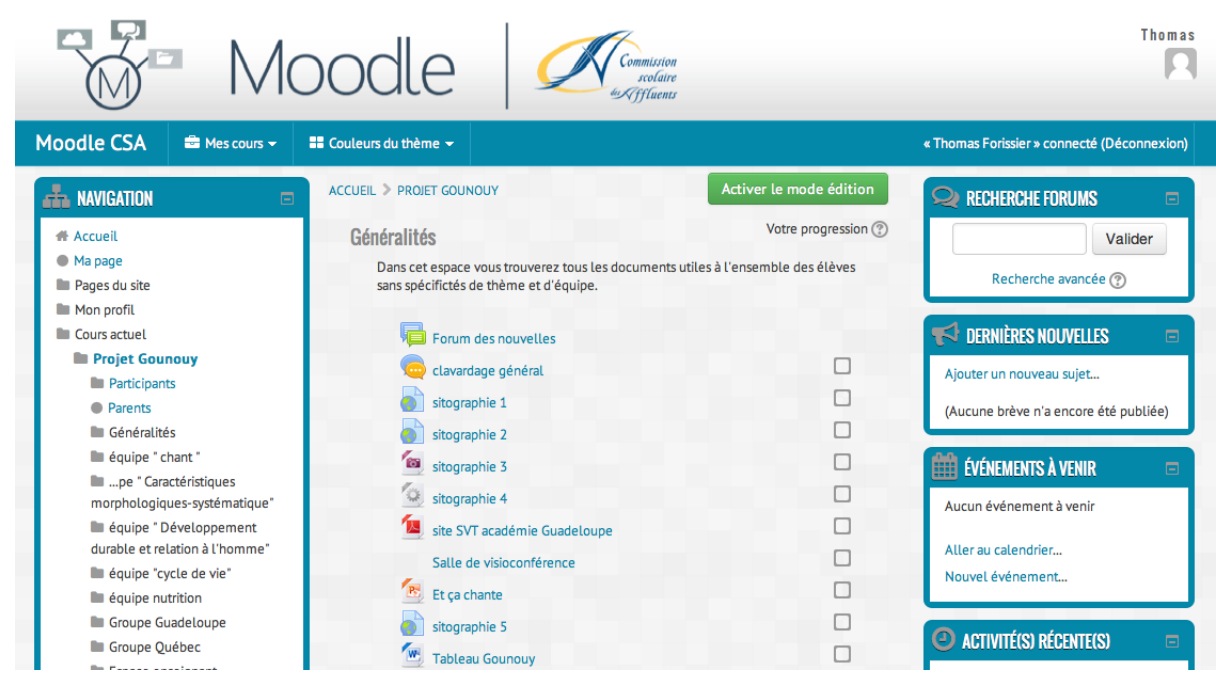

Fig. 2. The Moodle interface for teams working on the frog

Pre-test and post-test were conducted to detect mental representations on frogs (drawing the shape, giving the dimension, singing the call, etc). As it happened, the two teams, working in and on their own context (Fig. 3), changed their mental repre- 
sentations for more accurate ones, and became aware of the contextual differences (Fig.4), as was found in the video recordings.

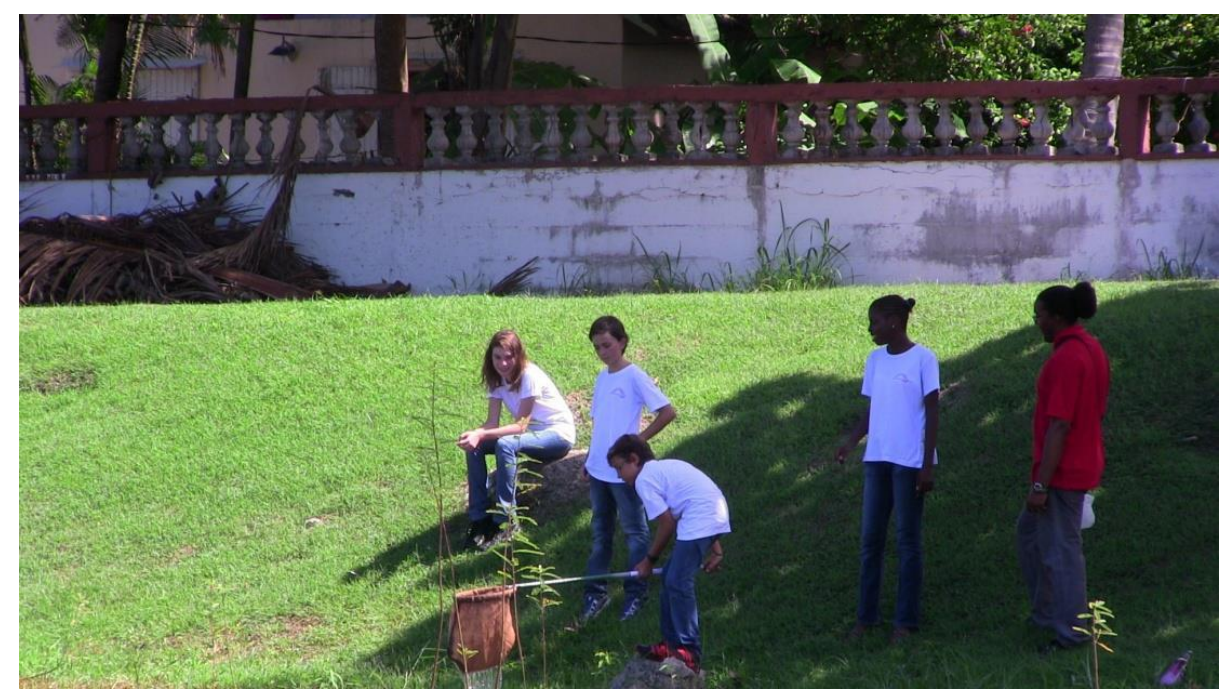

Fig. 3. Schoolkids trying to capture a frog.

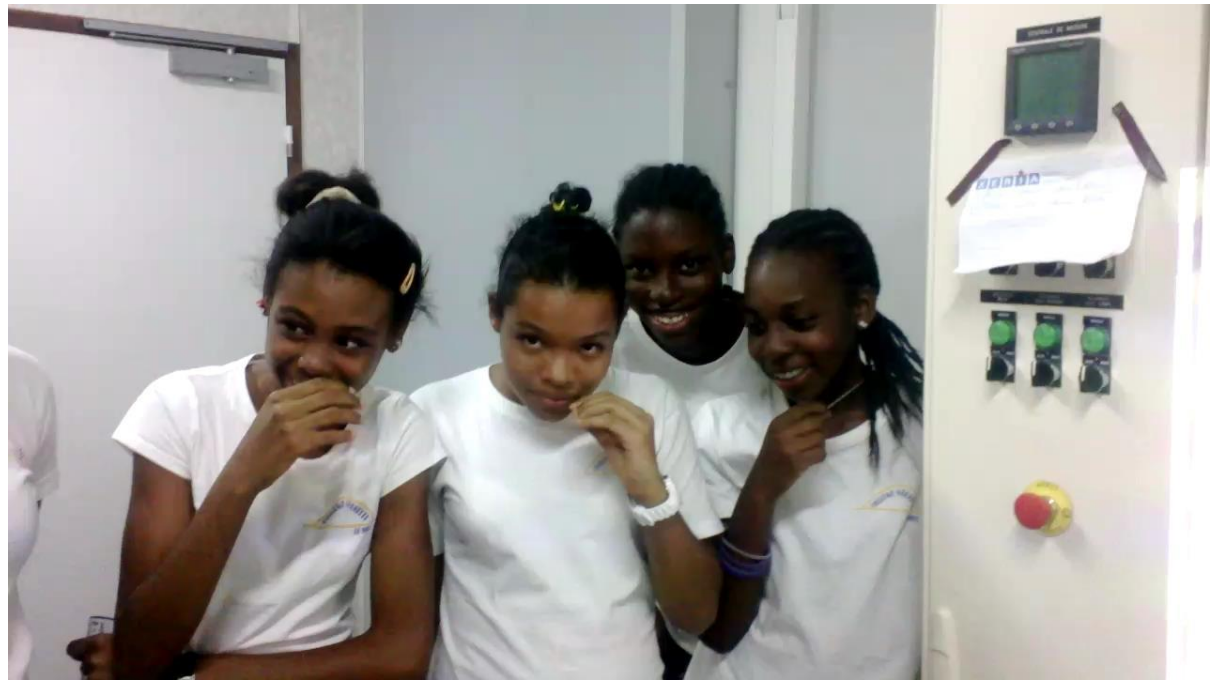

Fig. 4. The instant of surprise when discovering the foreign context. 
The experiment is well documented (in French) by the Quebec teacher Julie Poulin http://blogues.csaffluents.qc.ca/recit/2014/04/23/apprentissage-des-sciences-encontexte/, and by the Guadelupean teacher, Sophie Fécil [22].

In general, teachers and learners were happy with the experiment but learners said that they would like to exchange personally with their correspondent learners, as the teachers did.

\subsection{The Second Experiment in Environmental Science: Dlo}

The second experiment, called Dlo (water in creole), was realized with the same learners and teachers, Fécil and Poulin, and with the scientific support of Lise Parent (TÉLUQ), a water science expert, alias Dr Dlo, whose role was to answer difficult questions, but also ask some to the learners! The two teachers worked in collaboration to prepare the scenario on water analysis, as well as the resources and the permissions needed On both sides, the kids conducted an investigation on-site and in their science lab, before they exchange their results over videoconferencing (Fig. 4). However, unexpected technical problems happened. Due to the success of the Gounuij experiment, the school in Guadeloupe received a technical upgrade, early during the experiment, although without technical support to implement it. This became a problem that prevented the experiment to happen completely as planned.

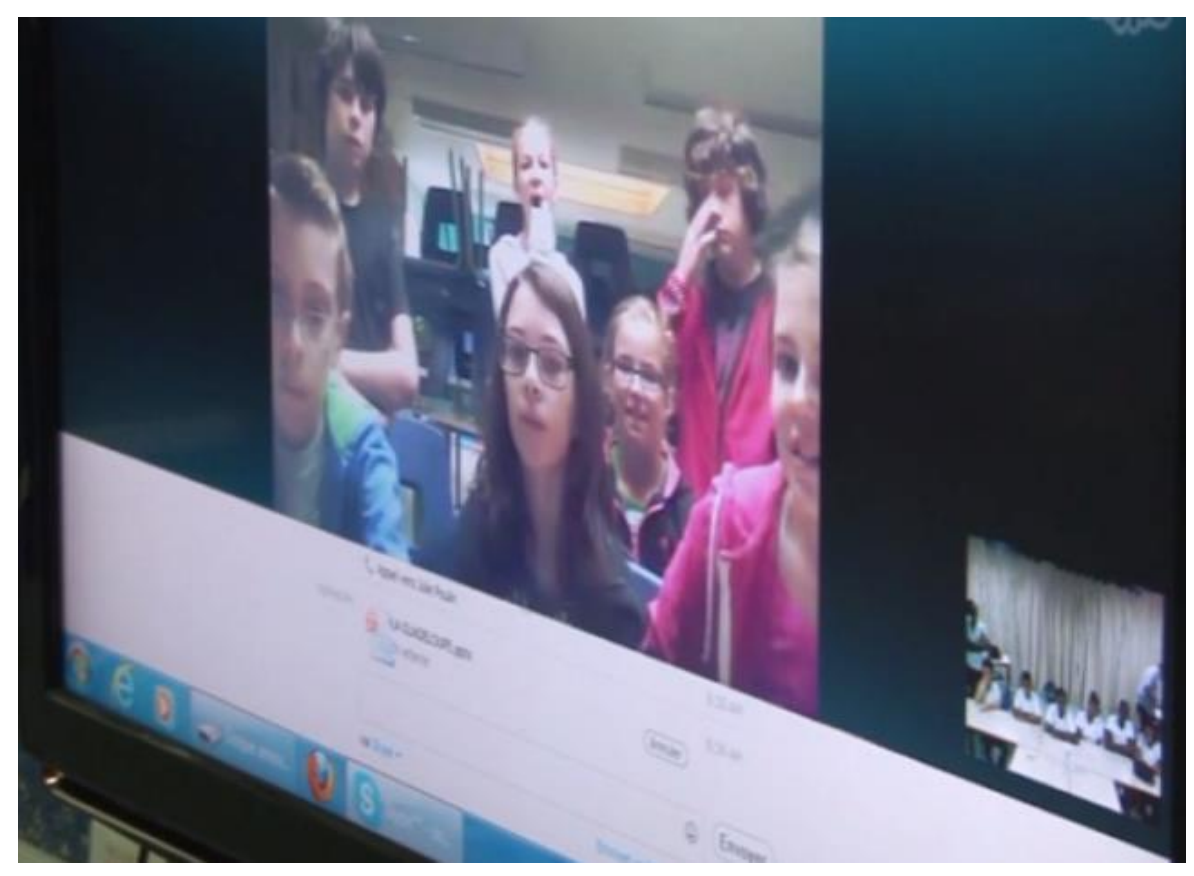

Fig. 4. Inter-groups Exchange over Videoconference 
The Dlo experiment will be re-planned after making sure that the technical problems are solved before starting the experiment.

\subsection{The Third Experiment in Geothermy}

The third design experiment is documented in a detailed way in Anjou et al's paper, 2017 (in this volume). The topics were: Geology, Geomorphology, Structural, Industry, Environment. The learning scenario included two groups of Teachers in Training from the Université des Antilles (UA) and Université du Québec à Montréal (UQAM), with the support of experts in Geothermy: Yves Mazabraud, (Université des Antilles), and Michel Malo and Jasmin Raymond (INRS-Québec).

This experiment highlighted the challenge of synchronization, since it became a major problem. Although the participants share the same time zone, their respective schedule was different and changing.

\section{$7 \quad$ Data collection and Trace Analysis}

Data collection is performed at each iteration, to test one or more elements of the system: hypotheses, model, instructional design, software design, and data collection tools. Video recordings are the main source of information about the collaboration process as well as about the individual learning process. At every stage, we extract lessons learned, new ideas, suggestions for improvement or extension for one or more elements of the system. These outputs are then used for the following iteration or development phase.

Between 2013 and 2016, for the tree design experiments described above (Gounouij, Dlo and Geothermy), we collected text-based traces and video recordings.

According to the plans for the following three years, from the beginning of 2017 to the end of 2019, with a similar corpus of data, we will enrich the trace analysis with two methods: analysis of epistemic interactions [23,24], and automatic detection of emotions in order to validate the visible expressions of the context effect in the video recordings [25].

\section{Overview of the DBR Iterations throughout the TEEC project}

An overview of the DBR iterations throughout the TEEC project is presented in Table 2, with already completed tasks (2012-2016), and the tasks planned for the coming three years (2017-2019), with iterations in three new domains: Socioeconomy, Environmental Science, and Language Learning. 


\begin{tabular}{|c|c|c|c|c|c|}
\hline $\begin{array}{l}\text { Itera- } \\
\text { tions }\end{array}$ & $\begin{array}{l}\text { CLASH } \\
\text { model }\end{array}$ & $\begin{array}{c}\text { MazCalc, } \\
\text { CAITS software }\end{array}$ & Learning scenarios & $\begin{array}{l}\text { Experimenta- } \\
\text { tions }\end{array}$ & Team \\
\hline 1-2012 & $\begin{array}{l}\text { Hypothesis } \\
\text { Objectives } \\
\text { Model version1 }\end{array}$ & $\begin{array}{l}\text { Inception, instantia- } \\
\text { ton to Biology, CAITS } \\
\text { architecture }\end{array}$ & $\begin{array}{l}\text { Biology } \\
\text { Gounouij (frog) } \\
6 \text { tasks }\end{array}$ & $\begin{array}{l}\text { Learners: } 10-12 \text { yrs } \\
\text { Video recordings } \\
\text { Pre-test, post test }\end{array}$ & $\begin{array}{l}\text { Bourdeau, Fécil, Forissier, Mazabraud, } \\
\text { Stockless, Poulin }\end{array}$ \\
\hline $2,-2013$ & $\begin{array}{l}\text { Refinement add- } \\
\text { ing internal con- } \\
\text { text }\end{array}$ & $\begin{array}{l}\text { Instantiation to Envi- } \\
\text { ronmental Science }\end{array}$ & $\begin{array}{l}\text { Environmental Science } \\
\text { Dlo (water) } \\
6 \text { tasks } \\
\end{array}$ & $\begin{array}{l}\text { Learners: } 10-12 \text { years } \\
\text { Pre-test post test }\end{array}$ & $\begin{array}{l}\text { Bourdeau, Forissier, Nkambou, Parent, } \\
\text { Stockless }\end{array}$ \\
\hline 3-2014 & $\begin{array}{l}\text { Refinement: } \\
\text { Characterisation } \\
\text { of parameters }\end{array}$ & $\begin{array}{l}\text { Development of meta- } \\
\text { model, structuration of } \\
\text { parameters }\end{array}$ & $\begin{array}{l}\text { Geothermy } \\
6 \text { tasks }\end{array}$ & $\begin{array}{l}\text { Teachers in Training } \\
\text { Video recordings } \\
\text { Pre-test post test }\end{array}$ & $\begin{array}{l}\text { Anjou, Bourdeau, Forissier, Fournier } \\
\text { Mazabraud, Stockless }\end{array}$ \\
\hline 4- $2015 / 16$ & $\begin{array}{l}\text { Predictive Analy- } \\
\text { sis }\end{array}$ & $\begin{array}{l}\text { Development of Excel } \\
\text { prototype in Geothermy }\end{array}$ & $\begin{array}{l}\text { Geothermy } \\
6 \text { tasks }\end{array}$ & Learners $12-14$ yrs & $\begin{array}{l}\text { Anjou, Bourdeau, Forissier, Fournier } \\
\text { Mazabraud, Stockless, , experts in } \\
\text { Geothermy }\end{array}$ \\
\hline \multirow[t]{3}{*}{$\begin{array}{l}\text { Planned: } \\
\text { 2017-2019 }\end{array}$} & $\begin{array}{l}\text { Validation and } \\
\text { improvement }\end{array}$ & $\begin{array}{l}\text { MazCalc development- } \\
\text { testing, release; CAITS } \\
\text { development-testing, }\end{array}$ & $\begin{array}{l}\text { Socio-economy, Language, } \\
\text { Environmental science }\end{array}$ & $\begin{array}{l}\text { Learners } 9-11 \text { yrs } \\
\text { Learners } 15 \text { yrs }\end{array}$ & $\begin{array}{l}\text { Anciaux, Anjou, Bourdeau, Candau, } \\
\text { Carignan Forissier, Fournier, Jeannot- } \\
\text { Fourcaud, Mazabraud, Nkambou, } \\
\text { Odacre Parent, Stockless, Temblay; }\end{array}$ \\
\hline & $\begin{array}{l}\text { Analysis of epis- } \\
\text { temic interactions }\end{array}$ & & & & Baker, Detienne, Bernard \\
\hline & $\begin{array}{l}\text { Automatic Emo- } \\
\text { tion detection }\end{array}$ & & & & Prevost \\
\hline
\end{tabular}

Table 2. Overview of the DBR iterations throughout the TEEC project 


\section{Current status and future work}

Thanks to the results obtained between 2013 and 2016, we have become confident that our approach is valid, despite the logistics problems encountered along the process. It is our plan to test this approach with three new domains: Socio-economy, Environmental Science, and Language Learning. The MazCalc context calculator will be fully developed, tested and documented, with a user guide. The Context-Aware Tutoring System (CAITS) will be developed with two user interfaces: the authoring interface to edit learning scenarios based on the MazCalc, and the tutoring interface to guide the learners through their tasks. In order to test and inform the CLASH model, we intend to add two new dimensions: trace analysis and emotion detection. Trace analysis is going to be performed in the way of the analysis of epistemic interactions among learners to identify the nature of interactions, and validate the manifestations of the context effect. Automatic detection of emotions will also validate the visible expressions of the context effect in the video recordings.

\section{Credits}

For their participation in this project and its experiments, I would like to thank: 1) the team members, Forissier, Delcroix, Anciaux, Mazabraud and Jeannot-Fourcaud, Université des Antilles; Tremblay, Parent, Carignan, and Savard,TÉLUQ; Stockless, Fournier et Nkambou, UQAM; Bernard, Université Paris-Descartes; Baker et Détienne, ParisTech; Prévost, ESIEA, Paris; 2) the experts, the research assistants, the teachers and the students; for English revision, Alexandra Luccioni.

Thanks also to the institutions and the research agencies that support our work: both research centers CRREF, Université des Antilles, and LICEF, Télé-université, 2012-2016; the ANR-FRQSC joint program for France-Québec projects, 2016-2019.

\section{References}

1. Brown, A. (1992). Design experiments: Theoretical and methodological challenges in creating complex interventions in classroom settings. Journal of the Learning Sciences, 2(2), 141-178.

2. Design-Based Research Collective. (2003). Design-based research: An emerging paradigm for educational inquiry. Educational Researcher, 32(1), 5-8.

3. Barab, S., \& Squire, K. (2004) Design based research: Putting a stake in the ground. The Journal of the Learning Sciences, 13(1): 1-14.

4. Wang, F., \& Hannafin, M. J. (2005). Design-based research and technology-enhanced learning environments. Educational technology research and development, 53(4), 5-23.

5. Herrington, J., McKenney, S., Reeves, T., \& Oliver, R. (2007). Design-based research and doctoral students: Guidelines for preparing a dissertation proposal. Murdoch University, http://researchrepository.murdoch.edu.au/6762/ 
6. Reimann, P. (2011) Design-based research, in L. Markauskaite, P. Freebody and J. Irwin (dir.). Methodological choice and design: Scholarship, policy and practice in social and educational research (p. 37-56). New York: Springer.

7. Sandoval, W., Bell, P. (2004). Design-Based Research Methods for Studying Learning in Context: Introduction. Educational Psychologist 39(4), 199-201.

8. Anderson, T., \& Shattuck, J. (2012). Design-based research a decade of progress in education research? Educational researcher, 41(1), 16-25.

9. Savard, Isabelle (2014). Modélisation des connaissances pour un design pédagogique intégrant les variables culturelles. Unpublished PhD Thesis. http://r-libre.teluq.ca/362/

10. Luccioni, A., Bourdeau, J., Nkambou, R., Coulombe, C. and Massardi, J. (2016). STIDICO: a Web-Based System for Intelligent Tutoring of Dictionary Skills. Proc. of the 25th International Conference Companion on World Wide Web (p. 923-928). Geneva, Switzerland: ACM.

11. Stockless, A. (2016). Le processus d'adoption d'une innovation pédagogique avec les TIC par les enseignants. Unpublished $\mathrm{PhD}$ thesis, Montréal : Université de Montréal.

12. Nkambou, R., Bourdeau, J, and Mizoguchi, R. (dir.). (2010). Advances in intelligent tutoring systems. Berlin: Springer, coll. Studies in Computational Intelligence.

13. Woolf, B. P. (2010). Building intelligent interactive tutors: Student-centered strategies for revolutionizing e-learning. Morgan Kaufmann.

14. Forissier T., Bourdeau J., Mazabraud, Y., and Nkambou, R. (2013). Modeling Context Effects in Science Learning:The CLASH Model. Proceedings of the 8th International and Interdisciplinary Conference (CONTEXT 2013) (p. 330-335). Berlin, Heidelberg : Springer Verlag, LNCS vol. 8175, http://r-libre.teluq.ca/253/

15. Gropper, G. (2017). Instructional Design. Educational Technology, vol. LVII, no. 1, 40-52.

16. Aronson, E. (1997). The jigsaw classroom: Building cooperation in the classroom. Scott Foresman \& Company., https://www.jigsaw.org

17. Erkens, M., Bodemer, D., \& Hoppe, H. U. (2016) Improving collaborative learning in the classroom: Text mining based grouping and representing. ijcscl 11 (4)

18. Berger, A., Moretti, R., Chastonay, P., Dillenbourg, P., Bchir, A., and Baddoura, R. (2001). Teaching community health by exploiting international socio-cultural and economical differences. In P. Dillenbourg, A. Eurelings, \& K. Hakkarainen (Eds.), Proceedings of the first European Conference on Computer Supported Collaborative Learning (pp. 97105) .Retrieved from http://www.eculturenet.org/mmi/euro-cscl/Papers/14.pdf

19. Anjou, C., Forissier, T., Bourdeau, J., Mazabraud, Y., Nkambou, R., Fournier, F. (2017) Elaborating the Context Calculator: A Design Experiment in Geothermy, accepted to the Context in Learning'17 Workshop.

20. Forissier, T., Bourdeau, J., Mazabraud, Y., Nkambou R.: Computing the Context Effect for Science Learning. In: Brézillon, P., Gonzalez, A.J. (eds.) Context in Computing, pp. 255269. Springer (2014)

21. Terdjimi, M., Médini, L., and Mrissa, M. (2016). Towards a Meta-model for Context in the Web of Things. In Karlsruhe Service Summit Workshop.

22. Fecil, S. (2014). Construire un Enseignement en tenant compte des Effets de Contexte, Unpublished. Master Thesis, Université des Antilles

23. Baker, M., Andriessen, J., Lund, K., Van Amelsvoort, M., Quignard, M.: Rainbow: A Framework for Analysing Computer-Mediated Pedagogical Debates. I J. CSCL, 2(2), 315357 (2007)

24. Bernard, F.-X \& Baker, M. (2009). CoFFEE, un environnement informatique pour l'apprentissage coopératif en co-présence. Actes du colloque «DIDAPRO », Université Paris 5, 21-22 avril 2008. Publications de l'INRP. [http://didapro.mutatice.net/] 
25. Nicolle, J., Rapp V., Bailly, K., Prevost, L. and Chetouani, M. (2012). Robust continuous prediction of human emotions using multi-scale dynamic cues, Workshop AVEC'12 (Audio/Visual Emotion Challenge), in conjunction with ICMI'12, pp 501-508. 